\title{
DOES SIGHT PREDOMINATE SOUND? ELECTROPHYSIOLOGICAL EVIDENCE FOR MULTISENSORY MISMATCH NEGATIVITY CORRELATION
}

\author{
Received January 14, 2013.
}

When being presented with consistent and repetitive sensory stimuli, the human brain creates a predictive "memory trace" against which subsequent stimuli are compared. When later stimuli do not match this predictive model, a highly localized negative shift in the brain polarity occurs. This response, known as the mismatch negativity (MMN), is believed to represent a pre-attentive deviance-detection mechanism that serves to provide direct attention toward unanticipated events. At present, there are conflicting data as to whether visually generated and auditorily generated MMNs interact, or whether they are mediated by independent sensory-specific networks. We present compelling evidence that visual and auditory MMNs are strongly correlated, and that, upon presentation of dual-sensory "audiovisual" deviants, this synergy is heavily dictated by an individual's unique visual response. This finding is suggestive of inhibitory interaction between the visual and auditory MMN networks. The characterization of this correlation helps one to explain (and explain away) much conflicting data published to date and opens the door to many questions regarding individual perception.

Keywords: event-related potentials (ERPs), mismatch negativity (MMN), multisensory perception, multisensory attention.

\section{INTRODUCTION}

The auditory mismatch negativity (aMMN) is an event-related potential (ERP) component elicited by any discernible violation in an otherwise consistent chain of auditory stimuli [1-3]. Peaking at several frontocentral scalp locations and approximately 100 $150 \mathrm{msec}$ post-violation under conditions of both attention and inattention, the aMMN is believed to reflect a pre-attentive auditory sensory memory that stores the characteristics of the standard stimuli against which any incoming sound is compared and determined to be "typical" or "deviant" [4-6]. It is largely believed that the major neural source of the aMMN is temporally located (bilateral auditory cortex) with a secondary frontal source involved in initiating

\footnotetext{
${ }^{1}$ University of Melbourne School of Psychological Sciences, Melbourne, Australia.

${ }^{2}$ Harvard Graduate School of Education, Cambridge, Massachusetts, USA.

${ }^{3}$ Berenson-Allen Center for Noninvasive Brain Stimulation, Beth Israel Deaconess Medical Center, Harvard Medical School, Boston, Massachusetts, USA.

${ }^{4}$ University of Maastricht, Faculty of Psychology and Neuroscience, Maastricht, the Netherlands.

Correspondence should be addressed to J. C. Horvath

(e-mail: jch155@mail.harvard.edu).
}

an involuntary attentional switch to the deviant sound [7-10].

Similarly to the aMMN, the visual mismatch negativity (vMMN) is an ERP component elicited by any discernible violation in an otherwise consistent chain of visual stimuli (for review, see [11, 12]). Despite several years of mild debate, the existence of the $\mathrm{vMMN}$ has been confirmed by a number of studies describing a negative deflection over the occipital pole peaking approximately $100-300 \mathrm{msec}$ post-violation under both attentive and inattentive conditions [13-18] (a debate regarding the temporal characteristics of this component has recently arisen [12]; we will explore this item in the Discussion). Like the aMMN, the $v M M N$ is theorized to reflect a pre-attentive visual sensory memory "regularity/violation" detection process $[12,14,19,20]$.

Despite their similarities, the aMMN and $v M M N$ are believed by many researchers to be exclusive processes generated and mediated by largely independent neural networks $[21,22]$. This uni-sensory hypothesis finds support not only in the unique scalp localizations of the individual MMN components but also in discrete data obtained from several experiments. For instance, under control conditions within a McGurk effect MMN paradigm, Sams et al. [23] simultaneously 
presented a consistent auditory speech stimulus (/pa/) with either a red (standard) or a green (deviant) visual circle. The deviant visual stimulus did not elicit an aMMN and had no discernible effect on frontal recordings, thereby suggesting dissociation between the two sensory modalities. More recently, Besle et al. [6] presented subjects with either pure auditory, pure visual, or paired audiovisual standard/ deviant combinations. These authors reported that the response to audiovisual deviants included both frontal and occipital components, suggesting the auditory and visual deviance-detection mechanisms were operating in a parallel manner and separately.

However, additional data obtained from the same experiments appear to support the opposite supposition: The aMMN and $\mathrm{vMMN}$ are correlated. Returning to Sams et al. [23], subjects were presented under experimental conditions with the same auditory speech stimulus (/pa/) time-paired, in this case, with either a congruent standard visual stimulus (a person mouthing/pa/) or an incongruous deviant visual stimulus (a person mouthing $/ \mathrm{ka} /$; the McGurk effect [24]). Sams [23] reported that, under this condition, the deviant visual stimulus generated a clear aMMN despite the fact that the auditory stimulus remained unchanged. Similarly, Besle et al. [6] reported that the vMMN elicited by audiovisual deviants was statistically different from the vMMN elicited by visual deviants alone, with two distinct peaks appearing at the occipital pole during audiovisual deviants, thereby suggesting an audiovisual interaction.

Despite a growing body of evidence supporting the correlative deviant detection hypothesis utilizing both the McGurk effect [25-28] and the ventriloquist illusion $[29,30]$, several researchers maintain the sensoryspecific MMN assumption, citing the special status of speech effects and the inherent nature of "illusions" to circumvent typical neural function [31, 32]. Adding fuel to this debate is the interexperimental variability reported by many audiovisual MMN researchers. For instance, Nyman et al. [21] presented subjects with either auditory or simultaneous audiovisual standard/deviant combinations. This research group reported no difference in the timing or amplitude of the evoked aMMN under either condition, a finding since replicated by several authors $[6,32]$. Utilizing a similar paradigm, other researchers, however, reported attenuated aMMN responses in the presence of visual deviations [33-35]. Accordingly, two questions loom large: Are the aMMN and $\mathrm{vMMN}$ correlated or do they represent independent uni-sensory deviant detection processes? What is to account for the discrepant findings reported both within and between experiments utilizing seemingly similar audiovisual oddball paradigms?

To examine these questions, we designed an oddball paradigm whereby audiovisual standards (AV) were interrupted by deviations to either the auditory domain $\left(\mathrm{A}^{\prime} \mathrm{V}\right)$, or the visual domain $\left(\mathrm{AV}^{\prime}\right)$, or both simultaneously $\left(\mathrm{A}^{\prime} \mathrm{V}^{\prime}\right)$. To avoid the earlier cited possible confounds of speech or illusion effects, we paired simple auditory beeps (deviating in pitch) with a simple checkerboard pattern (deviating in a color pattern). Our hypothesis was rather straightforward: If the aMMN and $\mathrm{vMMN}$ are correlated, then the neural activity measured in response to the dualsensory $\mathrm{A}^{\prime} \mathrm{V}^{\prime}$ should be different from the sum of the activity measured in response to the uni-sensory $\mathrm{A}^{\prime} \mathrm{V}$ and $\mathrm{AV}^{\prime}$. Conversely, if the two MMN components are independent, then the $\mathrm{A}^{\prime} \mathrm{V}^{\prime}$ response should reflect a simple summation of the $\mathrm{A}^{\prime} \mathrm{V}$ and $\mathrm{AV}^{\prime}$ responses.

\section{METHODS}

Participants. Eighteen healthy subjects $(10$ men and 8 women; ages $21-29, \mathrm{M}=23.8$ years, s.d. $=3.96$ ) volunteered to participate in this study. All subjects were right-handed with normal hearing and normal or corrected-to-normal vision.

Stimuli and Procedure. The standard auditory stimulus (A) was a $1,000 \mathrm{~Hz}$ sinusoidal tone played for $100 \mathrm{msec}$ (including 25-msec-long rise and fall times). The deviant auditory stimulus ( $\left.A^{\prime}\right)$ was a $1,200 \mathrm{~Hz}$ sinusoidal tone with the same timing parameters. Tones were played at a constant intensity (70 dB) through a central forward-facing central speaker located under the computer monitor.

The standard visual stimulus (V) was a $10 \times 10 \mathrm{~cm}$ checkerboard pattern with twenty-five $2 \times 2 \mathrm{~cm}$ internal squares. Alternating squares were either white or dark gray (67\% black). The deviant visual stimulus $\left(\mathrm{V}^{\prime}\right)$ was the same checkerboard; alternating squares were, however, either green (RGB values of 181, 230, and 29) or white. All stimuli were presented against a black background and consisted of simultaneous presentation of an auditory and visual feature. Each stimulus was presented for $100 \mathrm{msec}$ with constant ISIs of $300 \mathrm{msec}$ (off-set to on-set).

Following EEG set-up, subjects were seated in a dark soundproof room $80 \mathrm{~cm}$ from a computer screen. 
Prior to stimuli presentation, a fixation cross appeared in the center of the computer screen, and subjects were asked to stare at the cross for the duration of the study. Subjects completed a total of eight stimuluspresentation blocks, each lasting approximately $5 \mathrm{~min}$. Between blocks, subjects were allowed a 2-min-long break. Overall, subjects were exposed to 6,268 total stimuli; among them were 5,656 AV stimuli ( 90\%), $132 \mathrm{~A}^{\prime} \mathrm{V}$ stimuli $(\sim 2.5 \%), 132 \mathrm{AV}^{\prime}$ stimuli $(\sim 2.5 \%)$, and $348 \mathrm{~A}^{\prime} \mathrm{V}^{\prime}$ stimuli $(\sim 5 \%)$ presented in a randomized order.

EEG Recording and Analysis. Stimuli were presented using E-Prime 2.0 software (Psychology Software Tools Inc., USA) with event codes synched with the ERP recording system. EEG was continuously recorded via a QuickAmp amplifier with a system bandpass 0.016 to $70 \mathrm{~Hz}$ and a $500 \mathrm{sec}^{-1}$ digital sampling rate. Signals were recorded using the BrainRecorder software program and saved for future analysis. Thirty $\mathrm{Ag} / \mathrm{AgCl}$ ring electrodes were held in place by a fitted elastic cap and placed according to the international 10-20 system at scalp sites Fz, F3, F4, F7, F8, FC1, FC2, FC5, FC6, FT9, FT10, CZ, C3, C4, T7, T8, CP1, CP2, CP5, CP6, TP9, TP10, Pz, P3, P4, P7, P8, Oz, O1, and O2. Electrode sites were prepped with alcohol and NuPrep conductance gel. Vertical and horizontal eye movements were recorded via two electrodes placed at the left eye.

Data were digitally filtered off-line with a highpass filter of $0.01 \mathrm{~Hz}$ and a low-pass filter of $30 \mathrm{~Hz}$ and analyzed using an average reference. After filtering, samples were segmented into 500-mseclong epochs (starting $100 \mathrm{msec}$ pre-stimulus onset). Deviant trials occurring within $3 \mathrm{sec}$ of a previous deviant trial were discarded (as ample time is needed for subjects to re-acclimate to the standard stimuli). Trials with peak-to-peak EOG amplitudes exceeding $200 \mathrm{mV}$ were discarded to avoid blink or eye-movement contaminations. The remaining epochs were baseline-corrected and averaged, and a final waveform was constructed. Average peak (AP) measurements were performed between 110-145 msec post-stimulus onset (presented in $\mathrm{mV}$ ); AP values were not rectified to reflect the componential polarity. Accordingly, negative and positive values represented negative and positive polarity, respectively. One-way ANOVAs were run between average peak values at matching electrode sights across each condition.

Following initial grand average analysis, each subject's averaged $\mathrm{A}^{\prime} \mathrm{V}^{\prime}, \mathrm{A}^{\prime} \mathrm{V}$, and $\mathrm{AV}^{\prime}$ responses were subtracted from his/her unique averaged AV response at each electrode sight. This value represented the differential response between typical and deviant responses. These values were utilized in all correlation analyses.

\section{RESULTS}

Initial Analysis: Grand Average Comparison. Uni-sensory $\mathrm{A}^{\prime} \mathrm{V}$ and $\mathrm{AV}^{\prime}$ difference responses reveal large and easily recognizable aMMN and vMMN components (Fig. 1). With regard to $\mathrm{A}^{\prime} \mathrm{V}$ stimuli, a significant negative deflection over several frontal electrodes (primarily Fz, FC1, and F4) appeared approximately $90 \mathrm{msec}$ poststimulus onset and attenuated approximately $100 \mathrm{msec}$ later. With regard to $\mathrm{AV}^{\prime}$ stimuli, a significant negative deflection over several occipital electrodes (primarily $\mathrm{Oz}, \mathrm{O} 1$, and $\mathrm{O} 2$ ) appeared approximately $100 \mathrm{msec}$ post-stimulus onset and attenuated approximately $100 \mathrm{msec}$ later. These neural responses correlate well with the MMN characteristics described in the literature and suggest our stimuli were effective in eliciting individual MMN responses. In addition, a small negative deflection appeared in response to $\mathrm{A}^{\prime} \mathrm{V}^{\prime}$ deviants over several frontal channels, and a larger negative deflection appeared over the occipital pole. Both of these deflections began approximately $90 \mathrm{msec}$ post-stimulus onset and attenuated approximately $100 \mathrm{msec}$ later.

Peak-value descriptive and difference values for electrodes F4 and $\mathrm{Oz}$ can be seen in Table 1 . One-way ANOVA showed a significant difference between average responses at $\mathrm{F} 4$ across conditions $\left[F(3,68)=25.368, P<0.001, h^{2}=0.53\right]$. Post hoc analysis using the Bonferroni correction for multiple comparisons revealed a significant difference between $\mathrm{AV}$ and $\mathrm{AV}^{\prime}(M D=1.52$, $P<0.01), \mathrm{AV}$ and $\mathrm{A}^{\prime} \mathrm{V}(M D=1.83, P<0.001), \mathrm{A}^{\prime} \mathrm{V}^{\prime}$ and $\mathrm{AV}^{\prime}(M D=2.27, P<0.001), \mathrm{A}^{\prime} \mathrm{V}^{\prime}$ and $\mathrm{A}^{\prime} \mathrm{V}$ $(M D=1.08, P=0.048)$, and $\mathrm{AV}^{\prime}$ and $\mathrm{A}^{\prime} \mathrm{V}$ $(M D=3.35, P<0.001)$. No significant difference was found between $\mathrm{AV}$ and $\mathrm{A}^{\prime} \mathrm{V}^{\prime}(M D=0.747$, $P=0.376)$. One-way ANOVA showed a significant difference between average responses at $\mathrm{Oz}$ across conditions $[F(3,68)=23.564, P<0.001$, $\left.h^{2}=0.51\right]$. Post hoc analysis using the Bonferroni correction for multiple comparisons revealed a significant difference between $\mathrm{AV}$ and $\mathrm{A}^{\prime} \mathrm{V}^{\prime}$ 

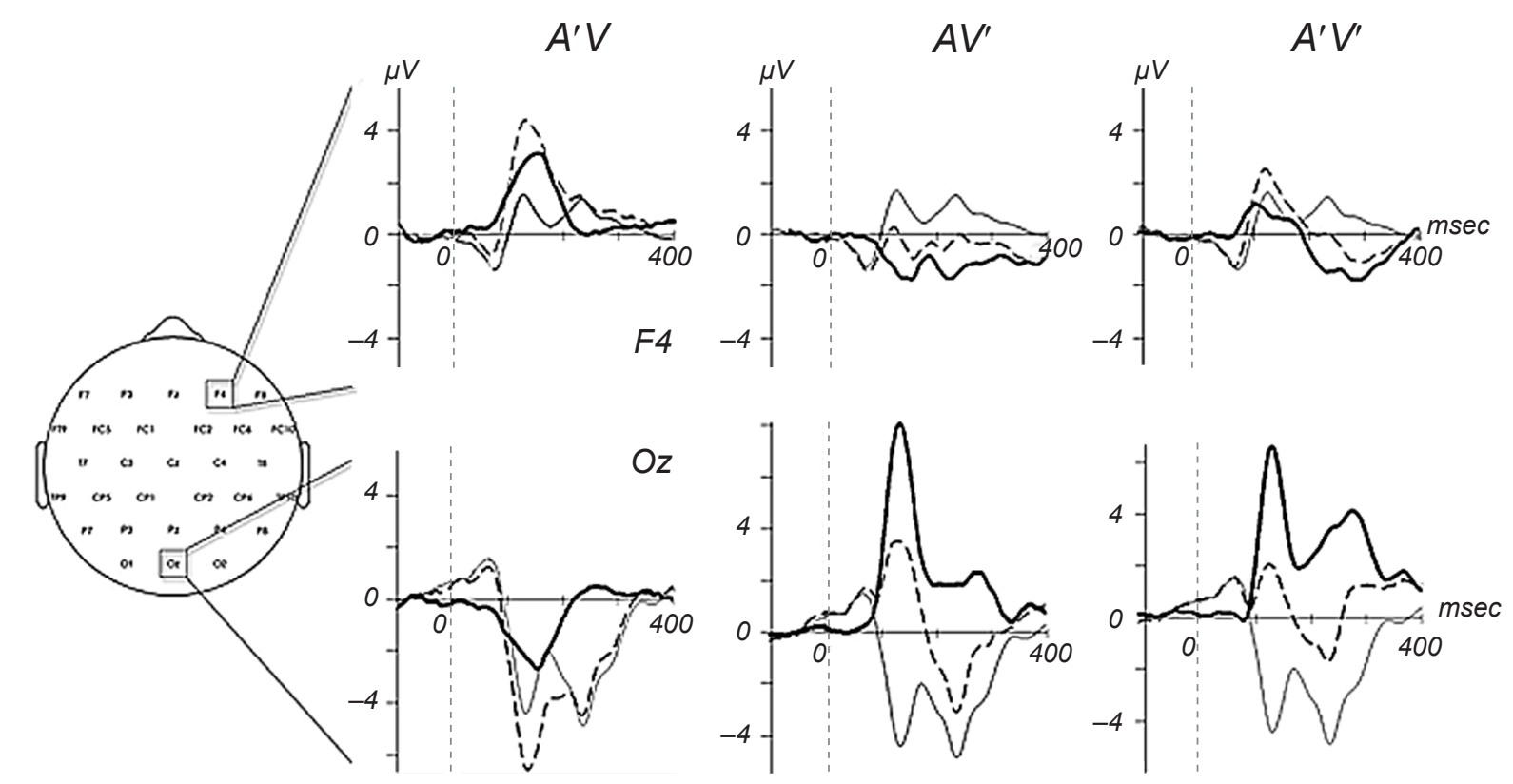

F i g. 1. Averaged potential waveforms elicited by audiovisual standards (AV), as compared to $A^{\prime} V, A V^{\prime}$, and $A^{\prime} V^{\prime}$ deviants over electrodes F4 and $\mathrm{Oz}$ from $100 \mathrm{msec}$ pre-stimulus to $400 \mathrm{msec}$ post-stimulus for all 18 subjects. Negative values are plotted upwards.

P и с. 1. Усереднені форми хвиль потенціалів, викликаних аудіовізуальними стандартними сигналами (AV) порівняно 3 їх девіантами ( $\mathrm{A}^{\prime} \mathrm{V}, \mathrm{AV}^{\prime}$ та $\left.\mathrm{A}^{\prime} \mathrm{V}^{\prime}\right)$, у межах від 100 мс перед пред'явленням стимулів до 400 мс після їх пред'явлення (у дослідження були залучені 18 людей; відведення від F4 та Oz).

$(M D=6.25, P<0.001), \mathrm{AV}$ and $\mathrm{AV}^{\prime}(M D=8.25$, $P<0.001), \mathrm{A}^{\prime} \mathrm{V}^{\prime}$ and $\mathrm{A}^{\prime} \mathrm{V}(M D=6.80, P<0.001)$, and $\mathrm{AV}^{\prime}$ and $\mathrm{A}^{\prime} \mathrm{V}(M D=8.80, P<0.001)$. No significant difference was found between AV and $\mathrm{A}^{\prime} \mathrm{V}(M D=0.55, P=1.00)$ or $\mathrm{A}^{\prime} \mathrm{V}^{\prime}$ and $\mathrm{AV}^{\prime}$ $(M D=2.00, P=0.749)$. These results suggest that there was no difference between vMMN responses to the pure visual and dual audiovisual deviants; however, there was a difference between aMMN responses to the pure auditory and dual audiovisual deviants.

Secondary Analysis: Visual and Auditory
Responses to $\mathbf{A}^{\prime} \mathbf{V}^{\prime}$ Stimuli. Examination of the individual difference data (as obtained by subtracting deviant values from standard values at each electrode) revealed strong negative correlation between responses at $\mathrm{Oz}$ (visual) and $\mathrm{F} 4$ (auditory) during $\mathrm{A}^{\prime} \mathrm{V}^{\prime}$ presentation $[r(17)=-0.83$, $P<0.001$; Fig. 2A]. This correlation suggests that, during $\mathrm{A}^{\prime} \mathrm{V}^{\prime}$ stimuli presentation, the stronger an individual's occipital negativity, the weaker his/her frontal negativity will be. A correlation analysis between individual difference data at $\mathrm{Oz}$

\section{Average Peak (AP) Values (110-145 msec) at Electrodes F4 and Oz across Each Condition}

Величини середніх максимумів (110-145 мс), відведених від F4 та Oz, в умовах пред'явлення стандартних стимулів (АV) та їх девіантів ( $\mathbf{A}^{\prime} \mathbf{V}, \mathbf{A} \mathbf{V}^{\prime}$ та $\left.\mathbf{A}^{\prime} \mathbf{V}^{\prime}\right)$

\begin{tabular}{l|c|c|c|c}
\hline \multirow{2}{*}{$\begin{array}{c}\text { Standard } \\
\text { and deviant } \\
\begin{array}{c}\text { audiovisual }(\mathrm{AV}) \\
\text { stimuli }\end{array}\end{array}$} & $\mathrm{F} 4 \mathrm{AP}(\mu \mathrm{V})$ & F4 difference $(\mu \mathrm{V})$ & Oz AP $(\mu \mathrm{V})$ & Oz difference $(\mu \mathrm{V})$ \\
\cline { 2 - 5 } $\mathrm{AV}$ & $-1.24 \pm 0.95$ & - & $3.48 \pm 1.71$ & - \\
$\mathrm{AV}^{\prime}$ & $0.29 \pm 1.51$ & $1.52 \pm 1.49$ & $-4.77 \pm 5.43$ & $-8.25 \pm 4.88$ \\
$\mathrm{~A}^{\prime} \mathrm{V}$ & $-3.06 \pm 0.91$ & $-1.83 \pm 0.78$ & $4.03 \pm 1.59$ & $0.55 \pm 0.63$ \\
$\mathrm{~A}^{\prime} \mathrm{V}^{\prime}$ & $-1.98 \pm 1.26$ & $-0.75 \pm 1.14$ & $-2.77 \pm 4.99$ & $-6.24 \pm 4.45$ \\
\hline
\end{tabular}

Footnote. Means \pm s.d. are shown. 
$A$

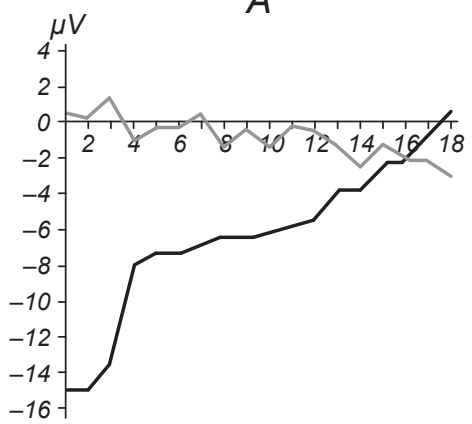

$B$

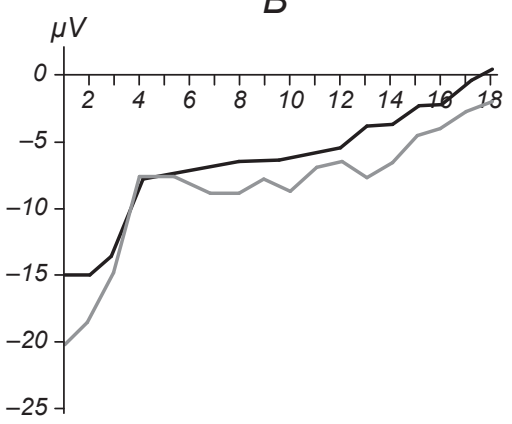

C

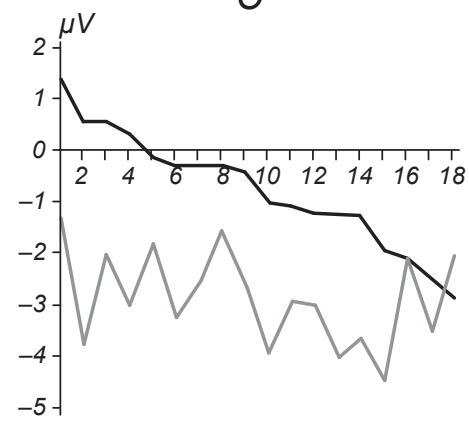

F i g. 2. Correlation between individual average peak (AP) values across conditions. A) Oz (dark line) and $\mathrm{F} 4$ during $\mathrm{A}^{\prime} \mathrm{V}^{\prime}$; data sorted according to Oz values. B) Oz during $\mathrm{A}^{\prime} \mathrm{V}^{\prime}$ (dark line) and $\mathrm{AV}^{\prime}$; data sorted according to $\mathrm{A}^{\prime} \mathrm{V}^{\prime}$ values. C) $\mathrm{F} 4$ during $\mathrm{A}^{\prime} \mathrm{V}^{\prime}$ (dark line) and $\mathrm{A}^{\prime} \mathrm{V}$; data sorted according to $\mathrm{A}^{\prime} \mathrm{V}^{\prime}$ values.

Р и с. 2. Кореляція між величинами індивідуальних середніх максимумів в умовах пред’явлення стимулів A'V'.
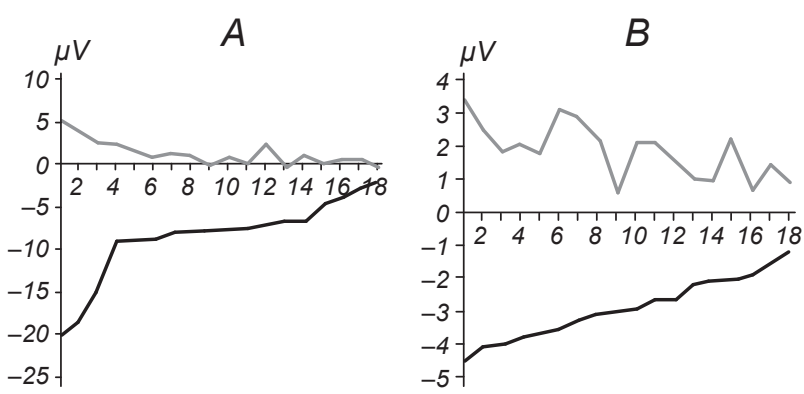

F i g. 3. Correlation between individual average peak (AP) values within conditions. A) $\mathrm{Oz}$ (dark line) and $\mathrm{F} 4$ during $\mathrm{AV}^{\prime}$; data sorted according to $\mathrm{Oz}$ values. B) F4 (dark line) and $\mathrm{Oz}$ during $\mathrm{A}^{\prime} \mathrm{V}$; data sorted according to $\mathrm{F} 4$ values.

Р и с. 3. Кореляція між величинами індивідуальних середніх максимумів в умовах пред'явлення стимулів A'V та AV'.

during the $\mathrm{A}^{\prime} \mathrm{V}^{\prime}$ and pure $\mathrm{AV}^{\prime}$ deviants revealed a very strong relationship $[r(17)=0.96, P<0.001$; Fig. 2B] A similar correlation analysis between individual difference data at $\mathrm{F} 4$ during the $\mathrm{A}^{\prime} \mathrm{V}^{\prime}$ and the pure $\mathrm{A}^{\prime} \mathrm{V}$ deviants revealed a weak insignificant correlation $[r(17)=0.35, P=0.159$; Fig. $2 \mathrm{C}]$. Extrapolated, these facts suggest that a response to pure visual deviants dictates how one responds to audiovisual oddballs; however, a response to pure auditory oddballs does not correlate with responses to mixed oddballs.

Tertiary Analysis: Visual and Auditory Responses during $\mathbf{A} \mathbf{V}^{\prime}$ and $\mathbf{A}^{\prime} \mathbf{V}$ Presentation. A close look at Fig. 1 reveals a significant positive deflection over frontal regions during $\mathrm{AV}^{\prime}$ presentation. To determine if the vMMN strength impacted this deflection, we ran correlation analysis between the difference values at $\mathrm{Oz}$ and $\mathrm{F} 4$ under $\mathrm{AV}^{\prime}$ condition. We found very strong correlation in this case $[r(17)=0.87, P<0.001$; Fig. 3A]. A similar analysis run between these electrodes under $\mathrm{A}^{\prime} \mathrm{V}$ condition revealed significant but somewhat weaker correlation $[r(17)=0.64$, $P<0.001$; Fig. 3B]. Taken together, these findings suggest that there is an inhibitory connection between occipital and frontal regions during MMN elicitation. Interestingly, this connection seems to show stronger activation during visual deviance detection.

\section{DISCUSSION}

Grand-average analysis revealed that a classical aMMN was elicited at F4 in response to $\mathrm{A}^{\prime} \mathrm{V}$ stimuli, and that a classical $v M M N$ was elicited at $\mathrm{Oz}$ in response to $\mathrm{AV}^{\prime}$ stimuli. These findings confirm that the stimuli utilized were effective. More interestingly, our data suggest that dual-sensory deviance $\left(\mathrm{A}^{\prime} \mathrm{V}^{\prime}\right)$ elicited a vMMN response with a highly attenuated aMMN response. Furthermore, the dual-deviance vMMN was not significantly different from the pure vMMN. This finding goes against the proposed summation theory (see [6]) and suggests that, in the presence of the specific dual-sensory stimuli we utilized, the visual deviance-detection mechanism appears to interact with the auditory deviance-detection mechanism.

Correlative examination of the data set revealed three additional interesting findings. First, there appears to be strong negative correlation between responses at the occipital pole and frontal sites during $\mathrm{A}^{\prime} \mathrm{V}^{\prime}$ presentation. More specifically, our data suggest that the stronger an individual's response to the visual dimension of a dual-sensory deviant is, 
the weaker their response to the auditory dimension will be (and vice versa). Second, there appears to be very strong positive correlation between the vMMN amplitude under both $\mathrm{AV}^{\prime}$ and $\mathrm{A}^{\prime} \mathrm{V}^{\prime}$ conditions. Put another way, our data suggest that an individual's response to a pure visual deviant will almost perfectly predict his/her response to the visual dimension of an audiovisual deviant (and, by extension, the auditory dimension as well). Interestingly, this correlation did not exist between the average aMMN amplitudes under $\mathrm{A}^{\prime} \mathrm{V}$ and $\mathrm{A}^{\prime} \mathrm{V}^{\prime}$ conditions. Third, there appears to be correlation between the pure MMN strength and positive deflection at the opposing MMN site. More specifically, the amplitude of an individual's vMMN $(\mathrm{Oz})$ can strongly predict the amount of positive deflection in the frontal regions (F4), and vice versa (although to a lesser extent). Unfortunately, the specific location of these positive defections is difficult to be determined. As such, it is uncertain whether these deflections represent inhibitory crosstalk between sensory specific deviance detection networks or simply regional patterns recorded by our analyzed electrodes.

To date, researchers have utilized an integrative sensory memory approach to explain any aMMN/ vMMN interaction. Put simply, it has been hypothesized that auditory and visual informations interact and form a combined audiovisual signal, at least in part before the pre-attentive MMN deviance detection process occurs. This hypothesis finds support in recent evidence suggesting that dual-sensory integration is realized very early in the process of sensory analysis [36-38]. However, an early interaction effect does not bring us any closer to explaining: Why, after sensory combination, the visual domain seems to dictate signal processing? To address this unique finding, we developed two possible theories. The first is that of a singular deviance-detection network. If the aMMN and vMMN spring from a singular network, one would expect the activity in each node to be reflected in the activity of the other node(s). This is close to what we see: During audiovisual deviance detection, the amplitude of the vMMN negatively fluctuates with the aMMN amplitude. However, beyond this, the singular network theory falls short. If both MMNs were generated by a unified network, then one would expect to see equal yet opposing fluctuations in the network under conditions of unisensory deviance. Although we see a strong frontal positive shift during exposure to pure visual deviants, we do not see an equally strong occipital positive shift during exposure to pure auditory deviants. Additionally, the unitary network concept does help us to explain why the $\mathrm{VMMN}$ seems to dictate the aMMN action, but not vice versa. Because of these shortcomings, we feel a second explanation is more apt: The individual MMN networks possess inhibitory connections. These connections appear to be bidirectional, although slightly stronger frontal-going than occipital-going. This explanation would not only explain the positive deflections during single-sensory deviations but would also explain why, under conditions of audiovisual deviation, the visual modality appears to assume precedence. To test this theory, one could present pure auditory and visual deviants in very close succession $(<100 \mathrm{msec})$ to determine if there is any response attenuation.

The strong variation in vMMNs between our subjects (as elicited by both the $\mathrm{A}^{\prime} \mathrm{V}^{\prime}$ and $\mathrm{AV}^{\prime}$ stimuli) is certainly worth noting (Fig. 2B). Despite these wildly different responses, the vMMN amplitude was still found to correspond strongly to the aMMN amplitude during audiovisual deviants, but not to the aMMN amplitude during pure auditory deviants. More specifically, the larger an individual's occipital negativity was in response to pure visual deviants, the smaller his/her frontal negativity in response to audiovisual deviants was (and vice versa). Interestingly, this variation may help us to answer a question asked in the Introduction (What is to account for the discrepant findings reported both within and between experiments utilizing seemingly similar audiovisual oddball paradigms?). As a reminder, Besle et al. [6] described both frontal and occipital negativities following audiovisual deviants. It is possible that the Besle's participant group displayed relatively small pure vMMN amplitudes. If this was the case, one would expect somewhat larger frontal negativity amplitudes during audiovisual deviant presentation, which, following grand-averaging, might certainly suggest a dual-negativity. Another example: Whereas Sittiprapaporn [32] reported no vMMN response to audiovisual deviants, Stekelenburg and Vroomen [33] found no aMMN response to audiovisual deviants. Again, it is possible that subjects in the former study might display very small (or no) pure vMMN responses, whereas subjects of the latter group might display very large pure vMMN responses. If this was the case, one would certainly expect to find no vMMN or aMMN in response to audiovisual deviants, respectively. Unfortunately, to determine the validity of these suppositions, additional protocols 
examining the effects of auditory-only and visual-only deviations should be undertaken. Stekelenburg and Vroomen [33] did not report a visual-only protocol, and Sittiprapaporn [32] did not discuss the effects of visual-only deviants in frontal electrode sites.

There are two final points worth briefly discussing with regard to our findings. The first is that of attention. As participants in this study were instructed to "look at the fixation cross" for the entire duration of the study, it is quite possible that different participants attended to different aspects of the presented stimuli. Whereas this might explain the variability between our subjects with regard to the vMMN amplitude (those attending to the visual dimension registered a larger vMMN), we feel this argument is unfounded for two reasons. First, despite some early debate [1, 39], it has long been established that the deviance-detection mechanism (and, by extension, the MMN component) is pre-attentive and shows minimal (if any) attenuation across varied conditions of overt or covert attention (for review, see [40, 41]). Second, any sensory-specific attention effects would likely be reflected in the pure $v s$ dual-sensory deviant responses (as participants would only have a "choice" of the preferred sensory modality during the audiovisual deviants). However, occipital responses under both the $\mathrm{A}^{\prime} \mathrm{V}^{\prime}$ and $\mathrm{AV}^{\prime}$ conditions were nearly identical (Fig. 2B). For these reasons, we, again, do not feel attention diversion is an explanation for (or shortcoming of) our findings.

A second point worth discussing is the temporal characteristics of the vMMN response. As alluded to in the Introduction, there is ongoing debate as to the precise temporal characteristics of the vMMN. Whereas many researchers reported a distinct occipital negativity peaking approximately $100-200 \mathrm{msec}$ postdeviant onset (for review, see [11]), it has recently been suggested that this component is merely a refractory effect, and that the true vMMN does not peak until 250-400 msec post-deviant onset (for review, see [12]). Attempts to resolve this question across varying visual domains via utilization of the equiprobable paradigm [42] have led to dissimilar conclusions (early vMMN [14, 16, 43] and late vMMN $[20,44])$. As we utilized a standard oddball paradigm, we do not feel our results speak to this debate. However, Czigler et al. [14] utilized visual color deviants in their equiprobable paradigm (very similar to that in our study) and concluded that the early negativity reflected the true vMMN. As such, we geared our analysis to reflect these findings.

Therefore, we have found compelling evidence that, with our utilized stimuli, the vMMN and aMMN appear to be correlated, and that this relationship may be strongly dictated by the response within the visual modality. We found that vMMNs elicited by our visual-only and audiovisual deviants do not differ from each other significantly, and that occipital negativity corresponds strongly to frontal positivity. In addition, we found that the vMMN response (and, by extension, the audiovisual deviant response) varies strongly between individuals. This variation could serve as an explanation for some of the conflicting data reported in the literature. Finally, we noted that, under conditions of uni-sensory deviant presentation, there appears to be considerable correlation between the MMN amplitude and positive deflection at the opposing sensory MMN site. Whether this fact represents inhibitory cross-talk or a more regional pattern, remains unknown. Future research is expedient to explore this relationship utilizing source localization protocols and exploring the precise temporal relationship between the MMN negativity and correlated positivity.

The study was carried out in compliance with generally accepted international and institutional ethical standards.

All subjects volunteered to participate in this study after providing written informed consent.

The authors, J. C. Horvath, L. Schilberg, and J. Thomson, have no conflict of interest.

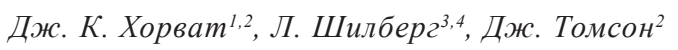

ЧИ ДІЙСНО ЗІР ПРЕВАЛЮЄ НАД СЛУХОМ? ЕЛЕКТРОФІЗІОЛОГІЧНИЙ ДОКАЗ КОРЕЛЯЦІЇ МУЛЬТИСЕНСОРНОЇ НЕГАТИВНОСТІ РОЗУЗГОДЖЕННЯ

\footnotetext{
${ }^{1}$ Інститут психологічних наук при Мельбурнському Університеті, Мельбурн (Австралія).

${ }^{2}$ Гарвардський університет, Кембрідж, Массачусетс

(США).

${ }^{3}$ Беренсон Ален-центр атравматичної стимуляції мозку, дослідницький медичний Бет Ізраель-центр, Гарвардська медична школа, Бостон, Массачусетс (США).

${ }^{4}$ Маастрихтський Університет (Нідерланди).
}

P е 3 ю м е

Під впливом стійких та повторних сенсорних стимулів мозок людини створює предиктивну енграму, з якою порівнюються наступні подразники. У випадку, коли останні стимули не відповідають створеній предиктивній моделі, відбувається особливо локалізоване негативне зміщення мозковій полярності. Вважають, що ця відповідь, відома як 
негативність розузгодження (НР), є преатентивним механізмом девіантності та детектування, забезпечуючим концентрацію прямої уваги на непередбачуваних подіях. Нині існують суперечливі дані щодо того, що процеси «візуально-» та «аудіогенерованої» НР безпосередньо взаємодіють або ж що така взаємодія опосередковується незалежними сенсорно специфічними нервовими мережами. Ми подаємо переконливі свідчення про те, що процеси зорового та слухового НР чітко корелюють. В разі пред'явлення подвійних сенсорних «аудіовізуальних» девіантів така синергія здебільшого диктується унікальною зоровою відповіддю особи. Отримані нами дані вказують на гальмівну взаємодію процесів НР у зорових та слухових нейронних мережах. Характеристика такої кореляції допомагає розтлумачити (та аргументувати) багато що із суперечливих відомостей, опублікованих нині, та розв'язати багато складних питань щодо індивідуального сприйняття.

\section{REFERENCES}

1. R. Näätänen, A. W. Gaillard, and S. Mäntysalo, "Early selective-attention effect on evoked potential reinterpreted," Acta Psychol., 42, No. 4, 313-329 (1978).

2. T. Kujala, M. Tervaniemi, and E. Schroger, "The mismatch negativity in cognitive and clinical neuroscience: theoretical and methodological considerations," Biol. Psychol., 74, No. 1, 1-19 (2007).

3. R. Näätänen, P. Paavilainen, T. Rinne, and K. Alho, "The mismatch negativity (MMN) in basic research of central auditory processing: a review," Clin. Neurophysiol., 118, No. 12, 2544-2590 (2007)

4. M. Sams, P. Paavilainen, K. Alho, and R. Näätänen, “Auditory frequency discrimination and event-related potential," Electroencephalogr. Clin. Neurophysiol., 62, No. 6, 437-448 (1985)

5. W. Ritter, D. Deacon, H. Gomes, et al., "The mismatch negativity of event-related potentials as a probe of transient auditory memory: a review," Ear Hear., 16, No. 1, 52-67 (1995).

6. J. Besle, A. Fort, and M. H. Giard, "Is the auditory sensory memory sensitive to visual information?" Exp. Brain Res., 166, Nos. 3/4, 337-344 (2005).

7. M. H. Giard, F. Perrin, J. Pernier, and P. Bouchet, "Brain generators implicated in the processing of auditory stimulus deviance: a topographic event-related potential study," Psychophysiology, 27, No. 6, 627-664 (1990).

8. B. Opitz, T. Rinne, A. Mecklinger, et al., "Differential contribution of frontal and temporal cortices to auditory change detection: fMRI and ERP results," Neuroimage, 15, No. 1, 167-174 (2002).

9. L. Y. Deouell, A. Parnes, N. Pickard, and R. T. Knight, "Spatial location is accurately tracked by human auditory sensory memory: evidence form the mismatch negativity," Eur. J. Neurosci., 24, No. 5, 1488-1494 (2006).

10. M. I. Garrido, J. M. Kilner, K. E. Stephan, and K. J. Friston, "The mismatch negativity: a review of underlying mechanisms," Clin. Neurophysiol., 120, No. 3, 453-463 (2009).

11. P. Pazo-Alvarez, F. Cadaveira, and E. Amenedo, "MMN in the visual modality: a review," Biol. Psychol., 63, No. 3, 199-236 (2003).

12. M. Kimura, E. Schröger, and I. Czigler, "Visual mismatch negativity and its importance in visual cognitive sciences," NeuroReport, 22, No. 14, 669-673 (2011).

13. K. Alho, D. L. Woods, A. Algazi, and R. Näätänen, "Intermodal selective attention. II. Effects of attentional load on processing of auditory and visual stimuli in central space," Electroencephalogr. Clin. Neurophysiol., 82, No. 5, 356-368 (1992).

14. I. Czigler, L. Balazs, and I. Winkler, "Memory-based detection of task-irrelevant visual changes," Psychophysiology, 36, No. 6, 869-873 (2002).

15. J. L. Kenemans, T. T. G. Jong, and M. N. Verbaten, "Detection of visual change: mismatch or rareness?" NeuroReport, 14, No. 9, 1239-1242 (2003).

16. P. Pazo-Alvarez, E. Amenedo, and F. Cadaveira, "Automatic detection of motion direction changes in the brain," Eur. J. Neurosci., 19, 1978-1986 (2004).

17. S. Berti and E. Schrцger, "Distraction effects in vision: behavioral and event-related potential indices," NeuroReport, 15, No. 4, 665-669 (2004)

18. C. Stagg, P. Hindley, A. Tales, and S. Butler, "Visual mismatch negativity: the detection of stimulus change," NeuroReport, 15, No. 4, 659-663 (2004).

19. I. Czigler, J. Weisz, and I. Winkler, "ERPs and deviance detection: visual mismatch negativity to repeated visual stimuli," Neurosci. Lett., 401, 178-182 (2006).

20. M. Kimura, J. Katayama, H. Ohira, and E. Schroger, "Visual mismatch negativity: new evidence from the equiprobable paradigm," Psychophysiology, 46, No. 2, $402-409$ (2009).

21. G. Nyman, K. Alho, P. Laurinen, et al., "Mismatch negativity (MMN) for sequences of auditory and visual stimuli: evidence for a mechanism specific to the auditory modality," Electroencephalogr. Clin. Neurophysiol., 77, No. 6, 436-444 (1990).

22. R. Näätänen, Attention and Brain Function, Lawrence Erlbaum Associates, Inc., Hillsdale, NJ (1992).

23. M. Sams, R. Aluanko, M. Hamalainen, et al., "Seeing speech: visual information from lip movements modifies activity in the human auditory cortex," Neurosci. Lett., 127, No. 1, 141-145 (1991).

24. H. McGurk and J. MacDonald, "Hearing lips and seeing voices," Nature, 264, No. 5588, 746-748 (1976).

25. R. Möttönen, C. M. Krause, K. Tiippana, and M. Sams, "Processing of changes in visual speech in the human auditory cortex," Cogn. Brain Res., 13, No. 3, 417-425 (2002).

26. C. Colin, M. Radeau, A. Soquet, et al., "Mismatch negativity evoked by the McGurk-MacDonald effect: a phonetic representation within short-term memory," Clin. Neurophysiol., 113, No. 40, 495-506 (2002).

27. C. Colin, M. Radeau, A. Soquet, and P. Deltenre, "Generalization of the generation of an MMN by illusory McGurk percepts: voiceless consonant," Clin. Neurophysiol., 115, No. 9, 1989-2000 (2004).

28. D. Saint-Amour, P. De Sanctis, S. Molholm, et al., "Seeing voices: high-density electrical mapping and source-analysis of the multisensory mismatch negativity evoked during the McGurk illusion," Neuropsychologia, 45, No. 3, 587-597 (2007).

29. C. Colin, M. Redeau, A. Soquet, et al., "Electrophysiology of spatial scene analysis: the mismatch negativity (MMN) is 
sensitive to the ventriloquism illusion," Clin. Neurophysiol., 113, No. 4, 507-518 (2002).

30. J. J. Stekelenburg and J. Vroomen, "An event-related potential investigation of the time-course of temporal ventriloquism," NeuroReport, 16, No. 6, 641-644 (2005).

31. A. Alsius, J. Navarra, R. Campbell, and S. Soto-Faraco, "Audiovisual integration of speech falters under high attention demands," Current Biol., 15, No. 9, 839-843 (2005).

32. W. Sittiprapaporn, "No visual mismatch negativity (MMN) for simultaneously presented audiovisual stimuli: evidence from human brain processing," Int. J. Appl. Biomed. Eng., 2, No. 2, 29-35 (2009).

33. J. J. Stekelenberg and J. Vroomen, "Neural correlates of audiovisual motion capture," Exp. Brain Res., 198, Nos. 2/3, 383-390 (2009).

34. X. Li, Y. Yany, and G. Ren, "Immediate integration of prosodic information from speech and visual information from pictures in the absence of focused attention: a mismatch negativity study," Neuroscience, 161, 59-66 (2009).

35. A. J. Andres, J. E. Oram Cardy, and M. F. Joanisse, "Congruency of auditory sounds and visual letters modulates mismatch negativity and P300 event-related potentials," Int. J. Psychophysiol., 79, No. 2, 137-146 (2011).

36. J. Besle, A. Fort, C. Delpuech, and M. H. Giard, "Bimodal speech: Early suppressive visual effects in human auditory cortex," Eur. J. Neurosci., 20, No. 8, 2225-2232 (2004).
37. A. Fort and M. H. Giard, "Multiple electrophysiological mechanisms of audio-visual integration in human perception," in: The Handbook of Multisensory Processes, G. Calvert, C. Spence, and B. Stein (eds.), MIT Press, Cambridge, MA (2004)

38. S. Watkins, L. Shams, S. Takana, et al., "Sound alters activity in human V1 in association with illusory visual perception," Neuroimage, 31, 1247-1256 (2006).

39. S. A. Hillyard, R. F. Hink, V. L. Schwent, and T. W. Picton, "Electrical signs of selective attention in the brain," Science, 182, No. 4108, 177-180 (1973).

40. A. Bendixen, L. SanMiguel, and E. Schroger, "Early electrophysiological indicators for predictive processing in audition: a review," Int. J. Psychophysiol., 83, 120-131 (2012).

41. S. Grimm and C. Escera, "Auditory deviance detection revisited: Evidence for a hierarchical novelty system," Int. J. Psychophysiol., 85, 88-92 (2012).

42. E. Schröger and C. Wolff, "Behavioral and electrophysiological effects of task-irrelevant sound change: A new distraction paradigm," Cogn. Brain Res., 7, 71-87 (1998).

43. P. Astikainene, E. Lillstrang, and T. Ruusuvirta, "Visual mismatch negativity to orientation changes: A memory-based process," Psychophysiology, 44, S8 (2007).

44. V. Mazza, M. Turatto, and M. Sarlo, "Rare stimuli or rare changes: What really matters for the brain?" NeuroReport, 16, 1061-1064 (2005). 